\title{
Dossiê
}

Dramaturgia Musical

Significação musical no contexto da cena multimedial: o caso Brecht-Weill

Geraldo Martins T. Jr. 


\section{Significação musical no contexto da cena multimedial: o caso de Brecht-Weill ${ }^{1}$}

Geraldo Martins T. Jr.

Um dos principais problemas nas teorias de Brecht sobre a música são as críticas sobre a sua aceitação irrefletida. Um expoente clássico destas críticas é Fowler, em seu trabalho sobre o gestus brechtiano intitulado Received truths (1987), que observa criticamente certos usos daquilo que Brecht deixou como legado em seus escritos, tratando conceitos e afirmações como "verdades aceitas". Seu estudo se concetra na recepção da teoria brechtiana sobre a música em cena, e procura mostrar como os estudiosos de Brecht usam os conceitos na análise da relação texto-música de maneira irrefletida. Ele também argumenta que Brecht não construiu uma teoria satisfatória para compreender a significação musical. Outros autores seguiram esta tendência crítica, como Rambo-Hood (2009), argumentando contra a possibilidade dos escritos de Brecht serem adequados ou suficientes teoricamente para se interpretar a significação musical por meio de conceitos como gestus, teatro épico e a brechtiana "separação dos elementos"2. Estes conceitos, principalmente na forma como Brecht os registrou no final da década de vinte e início da década de trinta ${ }^{3}$, se relacionavam com as montagem da época trazendo reflexões e propostas.

Neste artigo, vamos rever algumas críticas aos pressupostos teóricos de Brecht no que diz respeito à música em cena, especialmente com relação ao gestus e à separação entre os elementos. Em seguida, vamos trazer à discussão algumas contribuições que expandiram a questão da significação musical e da articulação dos elementos em Brecht e Weill, começando com Michael Morley em sua análise das canções Weill-Brecht (em especial a canção Barbarasong).

Vamos também considerar as contribuições da musicologia. Muitos dos problemas interpretativos sobre a significação musical num contexto de cena multimidiático ganham hoje outra perspectiva, se confrontados às questões que a musicologia têm colocado com relação à performance musical. A musicologia de Nicholas Cook reivindica a performance como algo constitutivo para a música, tanto em apresentações como também em análises musicais, abrindo caminho para pensar o teatro musical em sua pre-

1 Este artigo foi escrito a partir do capítulo "Significação Musical" da tese do mesmo autor: Dramaturgia, gestus e música. Estudos sobre a colaboração de Bertolt Brecht, Kurt Weill e Hanns Eisler, entre 1927 e 1932. Brasília, Universidade de Brasília, 2014.

2 Foi num texto de 1930, intitulado "Notas para a ópera Mahagonny" que Brecht anunciou sua "tábua" do teatro épico versus teatro dramático, argumentando logo em seguida que "a incursão dos métodos do teatro épico na ópera conduz, principalmente, a uma separação radical dos elementos deste gênero" (BRECHT, 1967: 60).

3 Aqui podemos citar as Notas sobre a ópera Mahagonny (1930), as Notas sobre a Ópera dos 3 vinténs (1931), A música-gestus (1932), as Notas sobre a peça A mãe (1933), O uso da música no Teatro Épico (1935), entre outros. 
sença, autonomia e heterogeneidade. Vamos ver como a análise da música em cena nos conecta à "musicologia da performance" de Cook.

Uma outra contribuição a ser utilizada é a de Erving Goffman em seu conceito de moldura, como uma forma de ampliar esta análise. Ao observar o ritmo e a forma dos cortes, interrupções e transformações de situações a partir das montagens de Brecht, podemos compreender os espetáculos como uma série de molduras que delimitam o roteiro de cena em seus desenhos, fluxos e interrupções.

Assim, este artigo procura trazer elementos para a criação de metodologias de composição da cena musical, ao tentar compreender a multimedialidade da cena a partir da música em Brecht-Weill.

\section{1 - Críticas aos pressupostos teóricos de Brecht sobre música}

\section{1 - Fowler e as "verdades aceitas" sobre Brecht}

Para Fowler, a teoria brechtiana não se revela adequada para uma investigação sobre a música em seus espetáculos. Ao mesmo tempo, ele faz uma crítica às interpretações feitas sobre as relações entre música e texto na obra de Brecht vindas de vários estudiosos, questionando a ausência de uma base teórica. Fowler tanto critica os pesquisadores quanto Brecht. Os primeiros, por não terem uma teoria da significação musical, Brecht por não ser uma "fundação teórica adequada para tal investigação". (FOWLER, abstract, 1987). Fowler analisa a canção Elogio do comunismo de Hanns Eisler, composta para o espetáculo A mãe, e escolhe as interpretações de Albrecht Dümling, Georg Kneple e Karl Schonewolf. ${ }^{4}$

Embora a crítica de Fowler aos pesquisadores proceda e seja o que mais aparece em sua argumentação, torna-se difícil descartar simplesmente os escritos teóricos de Brecht como uma "fundação teórica inadequada" para interpretar a significação musical. Seus espetáculos, sua prática, sua repercussão, entre muitos outros fatores, nos levam a tentar rever a questão por outros ângulos.

Sabe-se que os conceitos criados por Brecht foram revistos ao longo de sua prática. Fowler mesmo mostra, em sua investigação sobre o conceito de gestus, uma lista de noventa e uma ocorrências de palavras baseadas na raiz "gest" entre 1920 e 1955, encontradas nas obras completas de Brecht (Gesammelte Werke), informando o volume e a página ${ }^{5}$. Isto nos dá uma noção de como é difícil um trabalho conceitual mais preciso sobre a obra de Brecht. Esta dificuldade nos mostra que as reflexões teóricas, críticas e conceituais de Brecht se referiam muitas vezes a espetáculos que estavam sendo montados ou apresentados no momento. Em outros casos ele mesmo revê a forma como tra-

4 A escolha dos pesquisadores para as canções de Brecht é justificada por que "eles são representantes da maioria dos tipos de interpretação de canções entre os estudiosos de Brecht, e porque eles lidam com o mesmo trabalho" (FOWLER, 1987:10).

5 O anexo se chama Occurrences of words based on the root "Gest" in Brecht's theoretical works (Fowler, 1987: 89-91) 
balhava anos atrás. Devemos considerar as referências e descompassos existentes entre as produções teatrais e as produções teóricas numa análise histórica mais ampliada e comparativa. O valor da revisão conceitual empreendida por Brecht reside no fato de que a teoria esteve relacionada à prática e às propostas. Alguns conceitos, como o de "teatro épico", foram posteriormente abandonados. Enfim, é preciso ver como a teoria brechtiana pode ser contextualizada, de que forma os conceitos foram e ainda são usados, e em que medida eles apresentam resistências a uma compreensão mais ampliada. Considerando a polêmica Brecht-Weill ${ }^{6}$, o conceito de gestus apresenta uma resistência considerável, um espessor contraditório e por vezes polêmico.

Apesar disso, Fowler defende que o problema desta ausência da base teórica entre os estudiosos de Brecht esteja no uso de conceitos brechtianos (em especial o gestus e o estranhamento), imprecisos ou insuficientes em suas formulações teóricas sobre a relação entre música e texto. Porém, o próprio Fowler também não apresenta uma teoria de significação musical para compreender Brecht. Sua crítica se centra na recepção a-crítica da teoria brechtiana e nas dificuldades que esta recepção criou para uma investigação científica sobre o tema. Ele aponta um círculo vicioso entre Brecht e pesquisadores de forma que nem os primeiros e nem Brecht supre adequadamente as necessidades do outro. Por fim, termina questionando a possibilidade da música ser uma linguagem ou sistema sígnico.

Primeiramente, tornou-se claro que a recepção das categorias teóricas de Brecht pela crítica dificultou uma investigação científica sobre o tema. Ou seja, a teoria de Brecht foi um obstáculo para compreender o trabalho de Brecht. Depois, tornou-se claro que muitas análises não forneceram conexões entre a análise formal e suas interpretações metafóricas. Estes dois entendimentos, inevitavelmente entrelaçados, necessitaram tanto um reexame da teoria de Brecht (e sua recepção pelos críticos) como também uma investigação sobre as possibilidades da música ser uma linguagem ou um sistema sígnico (FOWLER, 1987: 3-4).

Fowler contribui para que repensemos metodologicamente uma abordagem à música em Brecht. Ele deixa transparecer que há saídas, que é possível criar "conexões entre análise formal e interpretações", ou uma "historicização crítica", embora não avance neste sentido. Seu esforço maior é apresentar o problema e mapeá-lo.

No contexto das canções, Fowler elenca várias análises que atrelam a teoria brechtiana previamente às conclusões analíticas, considerando as características da canção de uma forma superficial e não crítica. Ele cita várias canções em sua análise, mas resolve se aprofundar em Lob des Kommunismus, do espetáculo A mãe (1932). A crítica de Fowler às análises de Dümling (1985), Knepler (1982) e Schonewolf (1952), em suas interpretações de Lob des Kommunismus, mostra como "encontramos a ideia de que a música incorpora de alguma maneira o significado textual" (Ibidem: 25), tomando as afirmações

6 Entre outras questões, Weill também utilizava o conceito de gestus, mas de formas conflitantes às de Brecht. Para a polêmica Brecht-Weill, ver Stephen Hinton (1990, 1994, 2012), como também Kim, H. Kowalke $(1979,1989,1973)$ ou Michael John T. Gilbert $(1985,1988)$ 
de Brecht como "verdades aceitas" (received truth).

Dümling, então, demonstra várias atitudes que são peculiares aos estudiosos de Brecht com respeito a este assunto: ele não parece receber uma categoria-chave brechtiana (gestus) refletidamente; ele não oferece uma base metodológica para sua noção de significação musical; ele lida com a significação musical de modo afirmativo e não problemático (Ibidem: 18).

A crítica às leituras de Dümling se referem a como um determinado significado simbólico se associa a um elemento especificamente musical. Por exemplo: como o anapesto ${ }^{7}$ se associa ao conceito de luta de classes em A Decisão, como ele se torna "semantizado"? Para Fowler, a categoria rítmica do anapesto não pode ser tomada isoladamente para a produção deste significado, mesmo se o consideramos este uso uma característica do estilo de Eisler (Ibidem: 17).

Ao comparar a análise de Dumling com a de Knepler da canção Elogio do comunis$m o$, Fowler observa uma divergência de interpretações. Enquanto Dumling defende que os elementos musicais enfatizam a mensagem textual do comunismo "fácil de se fazer", Knepler defende que ela contradiz (Ibidem: 23). Fowler traz então uma terceira análise da mesma canção, feita agora por Schonewolf, que segue o mesmo caminho de Dumling. Fowler observa: "Uma vez mais encontramos a idéia da música que "fala", que expressa cordialidade e sinceridade (...) De novo encontramos a idéia de que a música, de alguma maneira, incorpora o significado textual" (Ibidem: 25).

Após mostrar a insuficiência de argumentos para a interpretação metafórica do texto frente à música (ou da música frente ao texto), Fowler aponta também a tendência em se generalizar as afirmações prescritivas de Brecht para todos os outros trabalhos (Ibidem: 32). "Brecht declarou implicitamente que a música tem um certo significado, e os críticos queriam demonstrar esta legitimidade da música" (Ibidem: 25), o que mostra uma "dependência por parte dos críticos das afirmações teóricas de Brecht sobre a função da música no teatro épico" (Ibidem: 45). Sobre a canção Lob des Kommunismus, Brecht afirma: "Na curta composição em que se responde à acusação de que o comunismo leva ao caos, o gestus amistoso e explicativo da música prende a atenção para a voz da razão." (BRECHT, 1967: 86). Como compreender o gestus amistoso e explicativo de Lob des Kommunismus? Como analisar o significado de uma canção na sua relação texto e música?

Nota-se que faltam elementos para aprofundar a análise, ou seja, falta considerar a música em seu contexto de performance cênica, e não apenas a partir de uma característica formal da música (como o anapesto), responsabilizando-a por uma significação metafórica em definitivo. Ao considerar a música em performance, consideramos também que estes significados metafóricos podem mudar durante a música, e se relacionam também com a montagem como um todo, e não se situam apenas na relação música-texto.

Ao abordar o conceito de estranhamento, Fowler admite que a música promove o estranhamento ao interromper a ilusão, ou seja, ao funcionar como um dos possíveis dis-

7 Anapesto - Idéia poética que, aplicada à música, sugere duas notas curtas e uma longa. 
positivos cênicos. Neste ponto, ele se refere não exatamente à linguagem musical, mas parece se referir à música como um dispositivo cênico que rompe a cena naturalista ao acontecer como apresentação musical e não mais como cena teatral ilusionista. Da mesma forma que os holofotes à mostra, ou as projeções de texto sobre as telas, "músicos visíveis confirmam a artificialidade do evento teatral" (FOWLER, 1987: 36). Embora aqui Fowler comece a falar da encenação, ele não avança muito neste aspecto. $\mathrm{O}$ exemplo trazido parece não tocar no âmago da questão que ele traz, ou seja: "Mas não fica claro de imediato como a música pode criar estranhamento em sua relação com o texto" (Ibidem: 36 ).

Fowler não desenvolve a relação da música com a encenação como um todo, da qual o texto é mais um de seus elementos. Ou seja, ele não avança sobre a questão da significação do espetáculo ser produzida pela relação entre os elementos - pois mesmo o texto teatral não possui uma significação própria, pura, descontextualizada, mas em performance e em interação com a atuação e a encenação. Porém, ele aponta para esta direção, na conclusão do trabalho. Contra o uso irrefletido da teoria brechtiana, ele propõe submeter a sua obra a uma análise histórica consistente e a uma abordagem mais relacionada ao contexto global da montagem. Esta perspectiva parece valer também para os conceitos brechtianos, se queremos interpretar seu possível uso na montagem de um espetáculo. Fowler sugere, ao se referir ao gestus:

Como na questão do gestus, sugere-se que uma forma de pensar mais relacional seja necessária. Com isso, quero dizer que não se deve tentar isolar o gestus de seu contexto na peça mas, ao contrário, entender que é o inteiro contexto de uma peça que determina se o gesto no palco se torna privado ou socialmente determinado. (Ibidem, 1987: 87-88).

Mas como realizar esta contextualização? Tanto a música, como as sonoridades de palco, assim como a iluminação, a atuação, o texto, entre outros elementos, ao se associarem, interagirem e formarem configurações inteiras em cena, podem produzir diferentes significações. Embora Fowler não tenha por objetivo ampliar esta perspectiva da relação entre os diversos elementos do espetáculo, ele a aponta como uma saída.

Por outro lado, Fowler pode ser lido como um argumento para se abandonar os escritos teóricos de Brecht e de seus estudiosos no que diz respeito à música em cena. Trazemos agora um trabalho que parece desqualificar por completo os registros teóricos de Brecht, criando outra forma de "verdade aceita".

\section{2 - Indo contra Brecht}

A tese de Rambo-Hood (2009) procura levantar as contradições existentes entre a música de alguns espetáculos e a teoria brechtiana do teatro épico. Se Fowler mostra um certo pessimismo, mas abre ainda algumas possibilidades de uma melhor contextualização, Rambo-Hood posiciona-se de forma definitiva: "Portanto, não é uma tarefa difícil para a música atender as demandas do teatro épico, é uma tarefa impossível” (RAMBO-HOOD, 2009: 142). O fato é que estamos diante de uma recusa à teoria brechtiana não a partir da crítica a seu uso irrefletido, mas a partir da exclusão de qualquer validade 
operativa dos conceitos e teorizações usadas por Brecht para a análise musical.

(...) embora meus três casos de estudo seguem em algumas partes a estrutura da música épica, eu argumentaria que esta estrutura não é viável como um dispositivo teatral. Isto ocorre devido às faltas que eu revelei tais como: o gestus indefinido, a idéia que os elementos do teatro não podem ser verdadeiramente separados e o fato de que o controle da platéia não pode ser completamente alcançado (Ibidem: 142).

A partir do reconhecimento de obstátulos interpretativos, a autora se centra numa suposta "inviabilidade" do teatro épico brechtiano, criticando os pressupostos de Brecht um a um, como numa check-list. Assim como Fowler, Ramboo-Hood não sugere uma metodologia de análise da significação musical a partir da materialidade histórica dos espetáculos. Mas é como se agora, por reconhecermos criticamente que houve uma consolidação irrefletida na produção teórica de um artista - a "canonização de Brecht" - tivéssemos que dar suas propostas como impossíveis em qualquer contexto.

Vamos por um momento observar o contexto de suas teorias. A separação dos elementos, por exemplo, não "pertence" a Brecht, mas a um movimento de vanguarda, a uma tendência estética que ia contra a fusão dos elementos, criando uma nova articulação da mímese em prol de uma antiteatralidade ${ }^{8}$. A separação dos elementos, o estranhamento, o distanciamento, o gestus, entre outros conceitos e procedimentos propostos, faziam parte de uma tendência geral das vanguardas históricas de se opor ao chamado teatro burguês, construindo, assim, uma crítica ao romantismo e ao naturalismo estrito das "coisas dadas".

É preciso ler os textos de Brecht como mais um dos elementos de compreensão do seu trabalho. Rambo-Hood chega a outro extremo, quando fala da relação Brecht-Weill:

Mas devido às tensões entre Brecht e Weill é impossível determinar o balanço apropriado entre música e texto nos casos da Ópera dos três vinténs. (Ibidem: 129).

Frente a este julgamento definitivo é preferível postular, com Gilbert, que as diferenças e tensões entre Brecht e Weill deram valor especial ao trabalho deles, “(...) tensões que foram, num primeiro momento, notavelmente produtivas (...)" (GILBERT, 1988: 55), tendência que podemos observar ao analisar os trabalhos, mesmo em suas conflitivas reedições e reinterpretações da dupla.

Como iremos ver, o acesso às obras de Brecht-Weill e Brecht-Eisler pode ser construído por uma metodologia independente, e não ficar preso às prescrições brechtianas ou weillianas. Por outro lado, isto não significa necessariamente o abandono das contribuições teóricas dos autores envolvidos no sentido de invalidá-las.

As críticas de Rambo-Hood cumprem um exercício de reconhecimento de limites,

8 Para antiteatralidade veja PUCHNER, Martin. Stage fright: modernism, anti-theatricality \& drama. Baltimore: The Johns Hopkins University Press, 2002. 
importante para os artistas hoje que buscam "aplicar Brecht" ou outro programa estético. Nota-se também que Rambo-Hood se baseou em Lehmann, no trecho em que ela traz o argumento de que "o teatro pós-dramático é o teatro pós-brechtiano" (RAMBO-HOOD, 2009: 141). Lehmann apresenta, além da provocação frontal à "autoridade" de Brecht, "capaz de ofuscar tudo à sua volta" (LEHMANN, 2007: 46), um horizonte provável de pesquisa que também incorpora Brecht ao ir além dele, mesmo que este "incorporar" seja o debate sobre suas lacunas no sentido de deixá-las para trás. Lehmann discute algumas afirmações de Andrzej Wirth, que defende um novo modelo de teatro épico herdado do teatro épico de Brecht. Para Wirth o teatro épico de Brecht era "uma invenção extremamente operativa e eficaz". Neste novo teatro épico, a tônica não mais estaria no texto, mas em todo o teatro que "fala" pelo diretor, na forma de uma "alocução". "A teoria de Brecht indica implicitamente que a declamação no teatro surge por meio da participação equivalente de elementos verbais e cinéticos (gesto) e não tem uma natureza meramente literária" (WIRTH apud LEHMANN, 2007: 50-51). Lehmann responde:

Mas será que os impulsos aqui mencionados vêm realmente do teatro de Brecht? Não viriam em igual medida da contestação desse teatro? Não será o gesto, compreendido de maneira tão geral, o cerne da atuação em todo teatro? E será possível descolar as invenções "operativas" de Brecht, sem uma profunda releitura de seus textos, das convenções ainda pressupostas do teatro de fábula com o qual o novo teatro rompeu? Com estas perguntas, a teoria de um teatro pós-dramático pode ser ligada às esclarecedoras considerações de Wirth sobre a herança brechtiana no novo teatro. (LEHMANN, 2007: 51)

Diante da imensa força hegemônica que o discurso multifacetado de Brecht adquiriu, as posições de Lehmann - assim como a de outros teóricos que criticam a aceitação irrefletida ou a hegemonia discursiva de Brecht - auxiliam na direção que assumimos ao optar por procurar os rastros dos espetáculos, "descolando-os" de uma obrigatoriedade de serem interpretados exclusivamente pelos pressupostos brechtianos, estejam eles ligados às noções de épico, fábula ou gestus. No antagonismo que Lehmann aponta entre gesto e fábula, em uma "tensão assimétrica" (Ibidem: 246), há um reconhecimento implícito de que Brecht é um artista da transitoriedade.

(...) deve-se pensar que a teoria de Brecht consiste de manifestações e textos nas feridas ainda abertas, que, em certo sentido não conseguimos apreendê-la por não existir num estado positivo de referência, mas que ainda deve ser encontrada através da leitura. Os seus textos devem ser lidos, as suas partes devem ser desmontadas e juntadas novamente em outras posições. (Ibidem: 250).

É o que pretendemos com relação aos textos teóricos de Brecht. Usá-los e criticá-los, porque usar Brecht sem criticá-lo é traí-lo, como disse Heiner Müller (MÜLLER, 1980). Neste sentido, iremos muito mais em direção ao gesto do que à fábula, pois o que mais nos interessa são as possibilidades de significação que o gestus cria, em suas interrupções e reconfigurações. Não se propõe aqui dar crédito à teoria brechtiana "em si mesma" mas 
discuti-la no momento em que nos apropriamos, desmontamos e remontamos as partes de seus espetáculos que são, para além dos textos, montagens interartísticas.

Foi nosso objetivo até aqui utilizar esta discussão sobre a teoria brechtiana como um diagnóstico e ponto de partida, o que nos levou inevitavelmente à concretude das montagens. Apresentamos então algumas alternativas de análise mais produtivas que ampliam o debate para além de uma perspectiva negativa e pessimista sobre o legado teórico de Brecht, procurando-o compreender em confronto com a sua prática.

\section{2 - Morley e os estágios do gestus musical}

Talvez o autor que mais trouxe bons insights na discussão sobre o gestus seja Michael Morley, em seu texto "Suiting the action to the word: some observations on gestus and gestiche musik" (MORLEY, 1986: 183-201), ao propor uma leitura do gestus musical de uma maneira focada na relação texto-música em performance. Morley busca "bons exemplos" na parceria Brecht-Weill, chamando a atenção para o seccionamento e articulação das partes das canções da dupla.

Uma das mais distintas características de uma canção de Brecht e Weill (mas, certamente, não apenas das canções deles) é o fato do texto e música, ao invés de simplesmente progredirem organicamente, procederem em estágios ou episódios. Uma seção distinta segue a outra ao invés de um todo emergir gradualmente do fluxo da música e texto juntos. (Em alguns casos, é claro, esta estrutura corresponde ao padrão verso/refrão ou uma simples forma A+B+C+refrão). (Ibidem: 192).

Morley toma a divisão comum de uma canção (verso/refrão, $\mathrm{A}+\mathrm{B}+\mathrm{C}+$ refrão), e utiliza cada uma destas partes para observar, dentro delas, algo como um subseccionamento deste momento em estágios e episódios. E são estas pequenas partes, ou situações dramáticas, presentes em canções tanto de Weill-Brecht quanto de Eisler-Brecht, que articulam a apresentação em molduras diferenciadas, recorrentes ou até opostas, permitindo explorar a contradição, a ironia, o comentário ou o distanciamento. Mas como isto ocorre?

Em primeiro lugar, cada canção apresenta o "embrião de uma situação dramática" (a dramatic situation in nuce) onde podemos ver o cantor-personagem contando e comentando uma história para a plateia, convidando o espectador a fazer parte desta apresentação (Ibidem: 191). Na canção Barbarasong, observamos que o texto de Brecht sugere uma atitude a ser sustentada, um gestus construído e mantido até o momento do refrão. Em seguida, ocorre uma mudança na apresentação dos elementos da canção (texto e música), ambos articulados - configurando um gestus diferente, que rompe de alguma maneira com a situação anteriormente apresentada.

Tanto o texto de Brecht quanto a música de Weill oferecem estágios intermediários em cada uma das seções que são úteis ao performer. Não somente porque eles também estão dando indicações para a cena, para o espaço, para a emoção dos personagens, mas também porque o performer pode então "dialogar" com a apresentação da canção intervindo nela, porque ele de alguma maneira a canta. Temos então uma expansão do binô- 
mio inicial texto-música e chegamos à apresentação, montagem e recepção, pois também o público também participa das transformações que os "estágios" sugerem.

Ao invés de representar apenas esta atitude, o performer é guiado pelo arranjo da música de Weill para mostrar atitudes em estágios. Este procedimento está muito perto da idéia de se encontrar os beats na fala de um personagem que articula uma mudança de humor ou intenção. Então, a seção de abertura da canção estabelece o gestus do contador de histórias e com ele uma atitude ingênua (talvez forçada), com a qual o público é convidado a compartilhar, não apenas durante o "eu era assim, como você", mas por meio do vívido balanço da música. (Ibidem: 192)

Estes estágios internos às partes principais da canção, portanto, funcionavam como "guias" de significação que serviam aos atores-cantores como referências contextuais produtivas para a sua performance. $\mathrm{O}$ que nos suscita indagar quais foram as possíveis articulações entre os elementos, com o intuito de compreender como a significação da cena foi produzida, configurada e percebida.

Vamos tomar inicialmente o gestus como um procedimento de separar ou interromper as seções maiores, mas também como um procedimento que cria pequenas separações ou mudanças no interior delas. Para Weill, significa separar em blocos de significação: “(...) concentrar-se em concisas células melódicas e rítmicas para comunicar musicalmente o núcleo dramático fundamental de uma cena” (Idem).

Se, por um lado, temos o gestus criando a dramaturgia dos momentos cênicos (Weill) temos ele também rompendo e opondo estes momentos entre si ou entre os elementos que os constituem (Brecht). Isto mostra como certas canções Weill-Brecht (e não todas) são "bons exemplos" no sentido que Morley busca. Ele observa que as canções da dupla "apresentam personagens em palco com uma justaposição episódica e alternância de atitude e comportamento que são refletidas na música", possibilitando que se trabalhe contradições ou similaridades entre texto e música. Mas em outras canções, compostas por Weill a partir de textos de Brecht (mas não num trabalho em conjunto), observa-se que "palavras e atitudes do cantor estão difusas e absorvidas pela música em si mesma" (Ibidem: 195) ${ }^{9}$. Estas últimas são mais convencionais, no sentido da música servir para uma aclimatação psicológica ou emocional da personagem.

Ou seja, os seccionamentos construídos nas canções permitem que seus rastros expressivos também articulem entre si estágios diferentes, possibilitando de forma expandida que a performance da atriz/ator, como também a encenação, participem da criação de significados. Para isso, participam os elementos como melodia, ritmo, instrumentação, entre outros, como também a dicção, fraseado e ritmo da fala do texto, como também as metáforas e construções textuais diversas utilizadas.

A mencionada "justaposição episódica" e "alternância de atitudes e comportamento"

9 Morley se refere especificamente às canções que Weill compôs posteriormente, em 1939: Nanas Lied e Und was bekam des Soldaten Weib? 
não estão inscritas na montagem buscando apenas criar a concordância dos elementos, mas sim possibilitando os contrastes que Brecht preconizava em seus (tão citados) textos teóricos. A música não seguia a cena mimeticamente em seu clima emocional ou descritivo, criando uma relação de fusão ${ }^{10}$. Por outro lado, Weill criava charmosas melodias e harmonias em cada um destes estágios que traziam efeitos singulares autônomos, disponíveis para serem aproveitados pelos atores-cantores, e muitas vezes sugerindo emoções ou metáforas em oposição, de forma irônica. Formavam-se momentos nos quais texto, música e performance se articulavam. Weill via o gestus como uma ampliação e mudança de foco na capacidade de comunicação da música. O resultado disso era múltiplo, fazendo do gestus uma expansão da cena em seus múltiplos canais. Tanto a música interrompe o fluxo da cena como também a nova configuração que se instaura traz, em seus seccionamentos, a articulação entre estes elementos que compõem a cena.

Aqui vamos procurar compreender não só a relação entre música e texto, mas como emerge uma configuração multimedial dos momentos em que as canções se relacionam com a cena que, por sua vez, se relaciona com todo o espetáculo. Se conseguimos identificar efeitos compartilhados entre texto, música e encenação, podemos procurar compreendê-los enquanto camadas que se relacionam, sendo a performance da canção uma articulação significativa e múltipla destas camadas em um mesmo momento de produção multimedial.

Ao apresentar o artigo de Morley, que tem a intenção prática e explícita de analisar "como e porque canções em particular são efetivas em sua combinação de palavra e música" (MORLEY, 1986: 183), demos um primeiro passo em direção ao gestus. Morley dá pistas para compreender a performatividade que a partitura e o texto sugerem. Reconhecemos nas partituras de Weill "episódios" diferentes entre si, que interagem com o texto e oferecem um material musical para o intérprete, delineando atitudes diferenciadas. Morley aponta para um modelo de interação texto-música-performance eficiente para a cena. Falta-nos compreender melhor como estes significados são produzidos dentro da cena. Como indagar, por exemplo - seguindo Brecht - se em Barbarasong a letra cantada se opõe à melodia? Como se dá a significação que este gestus propicia na articulação produzida pelos elementos em jogo?

Morley nos auxilia a compreender Barbarasong como um dos momentos de uma apresentação, como um momento que interrompe outros, que se insere em um fluxo que vinha ocorrendo. Para isso precisamos compreender a cena 3, em que momento ela aparece e o que acontece com a sua aparição. Precisamos também compreender como a letra organiza suas imagens e metáforas no jogo que ela cria com a música e vice-versa. Considerando todo o espetáculo, a tarefa se desdobra ainda mais: compreender como cada elemento cria vínculos com os outros elementos, compondo momentos multimediais delimitados, durante os quais são produzidas configurações próprias, específicas,

10 Lembrando aqui Tragtemberg ao questionar a afirmação: "a boa trilha sonora é aquela que não se percebe" (TRAGTENBERG, 1999: 13). A música criando uma relação de fusão tende a aclimatar, concordar, passar por imperceptível para que o que é mostrado seja sublinhado ou confirmado. 
diferentes de outros momentos, que podem romper, criar distanciamento, ritmo e uma significação que muitas vezes aponta para a plateia, rompendo com a quarta parede, entre outras possibilidades.

Para levar em conta as múltiplas interações dos elementos em performance, vamos trazer agora a contribuição de Cook para esta discussão. Para ele, a análise multimedial “(...) fornece um inventário de caminhos nos quais diferentes medialidades podem se relacionar entre si” (COOK, 1998: 98). Centrado em uma análise da música enquanto performance multimedial, Cook não deixa de lado o contexto de sua produção e de sua recepção.

\section{3 - Cook e o contexto da performance}

Cook lidou com a questão da significação musical em diversos trabalhos já publicados. Em Entre o processo e o produto - música elenquanto performance (2006) ${ }^{11}$, ele sugere uma alternativa entre dois enfoques antagônicos: entre uma "música pura", com um significado fornecido básica e exclusivamente pela sua partitura, e uma música cujo significado é construído social e culturalmente, sem nenhuma relação com seus caracteres musicais, ele sugere a análise da música "enquanto" performance. Ao invés de se conceber uma análise da música "e" sua performance - ou seja, uma consideração que separa a música original de suas leituras e execuções - introduz-se um demarcador conceitual importante, fazendo oposição à herança da musicologia centrada no texto musical como originário hierárquico de sua significação. A postura desta musicologia trata a significação musical não tanto como produto, mas como processo.

Depois da "virada performática" 12 nas artes cênicas, na década de sessenta, tivemos também, do ponto de vista da música e já na década de 80 , novos questionamentos em torno das relações entre música e performance. Ao reconhecer a proximidade desta nova abordagem da musicologia com os estudos sobre performance teatral, Cook ressitua a etnomusicologia, a análise musical de obras eruditas, como também as análises da música popular, que tomam a dimensão de "eventos". Cook apresenta outras abordagens também úteis à análise da música em performance (como a de Bahktin) ${ }^{13}$, defendendo uma compreensão da performance musical como uma participação do analista no evento musical. A interpretação não é uma leitura que aponta para algo que não está presente, como um original da música a ser adotado. A partitura é um script, não uma versão posterior de uma concepção original e, por isso, superior, anteriormente registrada num texto. A

11 Do original Music and/as performance (COOK, 2001).

12 Érika Fischer-Lichte considera que "A nova virada performática que emergiu na década de 60 e início da década de 70 é, em certos aspectos, reminiscente da virada performática que aconteceu na entrada do século XX" (FISCHER-LICHTE, 2005: 238)

13 "A imagem de linguagens diferentes sendo colocadas em contato entre si [...] nos oferece um fértil quadro de referência para a análise da performance musical e, mesmo, torna-se difícil pensar em uma área na qual os conceitos bahktinianos de heterogossia e discurso a duas vozes poderiam ser aplicados de uma maneira tão literal." (COOK, 2006: 16). 
música se constitui materialmente por mais elementos além da partitura, como o performer, os instrumentos, o local de produção e apresentação musical, entre outros (como técnicos de som, ou engenheiros de som no caso de gravações, etc.), todos fazendo parte daquela música, de alguma maneira.

$\mathrm{E}$ aqui chegamos às múltiplas relações, seja entre versões de uma partitura, versões de interpretações gravadas, como também pelas versões de performances que um texto ou uma partitura suscitam ao performer em uma produção de palco. E estas relações entre o performer cênico-musical e os textos (teatral e musical) podem ser vistas de forma a fundir-se, a concordarem parcialmente entre si ou a se oporem.

Se adotamos uma fonte como uma referência "anterior" ou "externa" à performance que deve ser seguida, adotamos um modelo de hierarquia entre os elementos, aquilo que Brecht chamava de "predominância de um elemento sobre o outro", o que cria problemas tanto para a performance musical quanto para a performance cênica, limitando, como consequência, que a performance do espetáculo musical possa explorar novas leituras e situações que permitem articulações mais criativas.

O modelo tradicional de transmissão musical, que vem da filologia, é o estema: um tipo de árvore genealógica na qual as interpretações musicais sucessivas (quer sejam grafadas ou interpretadas [performed]) se distanciam verticalmente da visão original do compositor. A crítica das fontes procura reverter este caminho e reconstruir a visão original, ao passo que a performance historicamente informada objetiva traduzi-la em som. Mas o paradigma dos estudos de performance muda a direção deste modelo ortogonalmente: como expressa Richard SCHECHNER (1988: 28), a ênfase recai sobre "explorações de relações horizontais entre formas afins, ao invés de uma busca vertical por origens improváveis". Uma das mais óbvias implicações disto para a musicologia da performance é que as performances devem ser compreendidas não apenas em relação às obras "das" quais são performance, mas em relação às suas "formas afins", ou seja, às outras performances (...). (COOK, 2006: 12).

As diversas versões que uma música composta pode receber não a "afastam" do que ela "é", mas ajudam a compor sua complexidade interpretativa, sua horizontalidade.

O alinhamento que Cook faz da musicologia com os estudos da performance pode ser bastante útil para departamentos de música ou de artes cênicas que buscam algum diálogo e novos caminhos para trabalharem juntos. Esta aproximação interdisciplinar é uma mudança de hábitos que pode ser vista no tratamento que o teatro passou a dar aos textos teatrais, que passaram a ser vistos como roteiros de cena, e não mais como origem de significação do drama. A partitura, por sua vez, é um roteiro para uma performance, e é esta performance que constitui a valor significativo daquela música apresentada. Ao atribuir valor estético e cênico à apresentação, a música como performance deixa de ser considerada apenas uma "versão do original", criado pelo compositor, e passa a ser considerada em sua materialidade. Seja na configuração de sua apresentação em shows ou espetáculos, seja na forma da gravação daquela canção - o que implica aqui em outra forma de produtividade, não presencial, mas que passou a dominar os espaços de difusão 
no século XX - a música passa a ser compreendida a partir daquilo que a materializa: seus suportes expressivos diretos (o timbre instrumental, o corpo que canta, o aparato de reverberação, etc.), outros elementos artísticos de seu contexto multimidiático (como iluminação, atuação, texto, encenação), e os suportes técnicos que criam reprodutibilidade $^{14}$, quando houver (vinil, CD, rádio, TV, internet, entre outros) - reprodutibilidade que também pode ocupar o espaço da cena.

Portanto, todas as nuances ou recursos introduzidos em performances e tradicionalmente não grafadas em partituras tornam-se atributos das músicas, entendidos como parte constitutivas de suas performances, e não como acréscimos que aquela música recebeu por estar "em performance" naquela situação. Considerando a expansão desta concepção, procuraremos compreender estas músicas e canções em performances heterogêneas, múltiplas, em relação a outros elementos estéticos. Quando Brecht recomenda que os atores cantem "contra melodia ou contra a letra", ou que seja inserida uma "luz dourada" durante a canção, ele não está somente sugerindo um aspecto da encenação ou da performance, mas está também compondo musicalmente, pois está introduzindo elementos que compõem a performance musical. Portanto, a partitura-roteiro de Barbarasong, que introduz seções musicais diferenciadas ao interagir com o texto poético de Brecht, dirige-se à criação de situações de performance em um processo de significação múltiplo e articulado, e não exclusivamente a uma significação a ser "executada" segundo os seus caracteres grafados.

Com esta perspectiva, nos aproximamos de um paradigma interpretativo e contextual para a compreensão deste processo de significação. Como Cook observa em seu ensaio Theorizing musical meaning $(2001)^{15}$ :

Como é construído em performance, então, o significado é emergente: ele não é reproduzido na performance, mas criado por meio do ato da performance. [...] Como objetos físicos, os traços materiais da música suportam uma porção de significados possíveis, [...] eles podem ser considerados como agrupamentos constituídos de um número indefinido de atributos dos quais diferentes seleções serão feitas dentro de tradições culturais diferentes, ou em diferentes momentos de interpretação. (COOK, 2001: 179).

Em seu livro Analysing musical multimedia (1998) ele sugere caminhos de análise destes atributos. Por exemplo, na relação entre a música e os outros elementos de um comercial veiculado em vídeo, ele diz:

Mas a significação particular destes atributos ou qualidades - seu significado em termos do comercial - emergem de sua interação com a linha da história,

14 Entre outras atribuições, Cook é pesquisador associado e professor no Departamento de Música da Royal Holloway - University of London, onde coordena o grupo de pesquisa CHARM (Centro de História e Análise da Música Gravada).

15 Este ensaio foi posteriormente republicado em uma coletânea intitulada Music, performance, meaning (COOK, 2007: 213-240). 
a voz em offe as imagens. Se a música dá significado às imagens, estas também dão significado à música. (...) o significado é construído e negociado dentro do contexto do comercial. Neste caso, ao contrário de falar em um significado que a música tem nós deveríamos falar desse significado como algo que a música faz (ou a ela fizeram) dentro de um dado contexto. (COOK, 1998: 8-9)

As diferentes mídias e sua troca ou transferência de atributos constroem uma significação e não simplesmente comunicam. Elas mediam. (Ibidem: 261). Cook propõe que a análise da relação entre os elementos seja focada nos momentos em que esta relação entre elementos ocorre, observando como a significação é produzida naqueles momentos multimediais - IMM (instances of multimedia) (Ibidem: 100). Em geral, vai estar em jogo o foco do analista e o contexto da situação, mas é preciso que haja o que ele chama de uma "gradação na autonomia" de cada elemento, ou "uma dimensão independente de variação":

O que estamos dizendo é que, no balé (...) há uma gradação de autonomia entre música e dança; eles constituem dimensões diferentes de variação (para tomar emprestado o termo de Levinson), e o esfeito estético do balé emerge da interação entre os dois. (...) Em contraste, poderia ser estranho chamar a performance de violão clássico um momento multimedial, a despeito do fato de que ela consiste nos mesmos dois componentes: som musical e gesto físico. A razão é que o gesto físico é intensamente determinado pelo som. (...) Ao mesmo tempo, há guitarristas - e agora eu estou pensando no rock ao invés dos guitarristas clássicos - que utilizam seus corpos em um contraponto genuíno com a música. Jimi Hendrix é um exemplo óbvio; suas performances de palco eram tanto dança quanto música; enquanto seus movimentos físicos eram inevitavelmente vinculados à música (como no caso do balé), eles iam muito além disso. Eles se tornavam uma dimensão independente de variação naquilo que pode ser chamado perfeita e apropriadamente de momentos multimediais. (Ibidem: 263).

É importante notar que Cook trata a performance não apenas como prática ou desempenho, mas em sua materialidade produtiva, sua autonomia, que possibilitam a heterogeneidade do contexto da cena. Seus "momentos multimediais" procuram criar um foco próximo ao fenômeno, que acontece na interação entre os elementos, delimitando estas interações como "momentos", o que vai ao encontro do que estávamos falando em Morley, com relação aos "estágios". Além disso, ele fala em "grau de autonomia" de cada um dos elementos, o que interessa a um contexto teatral que não quer se prender à mímese da cópia. Se a música somente ilustra (Brecht), não há uma dimensão de variação, mas de similaridade e hierarquia, na qual um elemento segue o outro.

Brecht aponta para novas relações entre os elementos em seu texto Notas para Mahagonny (1930), apresentando uma lista de características opostas entre o teatro dramático e o teatro épico (BRECHT, 1967: 59). Um dos pólos aponta para o teatro dramático, mimético, subserviente, no sentido da cópia e da ocultação de seus desdobramentos, tendendo à homogeneidade e à fusão. O outro, o épico, descrevendo um teatro de saltos, de inter- 
rupções e articulações diferenciadas ou opositivas, na direção de um anti-teatro. Embora o modelo brechtiano não fosse polarizado, mas permitia matizes entre os pólos ${ }^{16}$, Brecht não se deteve muito em detalhar os pormenores conceituais e práticos do que seriam estas matizes deste espaço intermediário entre o épico e o dramático.

O modelo que Cook propõe para interpretar os "instances of multimedia" (IMM) se subdivide não apenas em duas, mas em três possibilidades: conformidade, complementariedade e disputa. Há também quatro atributos (consistência, coerência, contrário e contradição) que representam o que ocorre com os elementos envolvidos no IMM. Cook sugere dois testes para um possível mapeamento dos elementos em interação: teste de similaridade e teste de diferença. O teste de similaridade ${ }^{17}$ define se o IMM é uma conformidade ou não e, caso não seja, faz-se o teste da diferença. Abaixo o gráfico que ele utiliza para ilustrar a proposta:

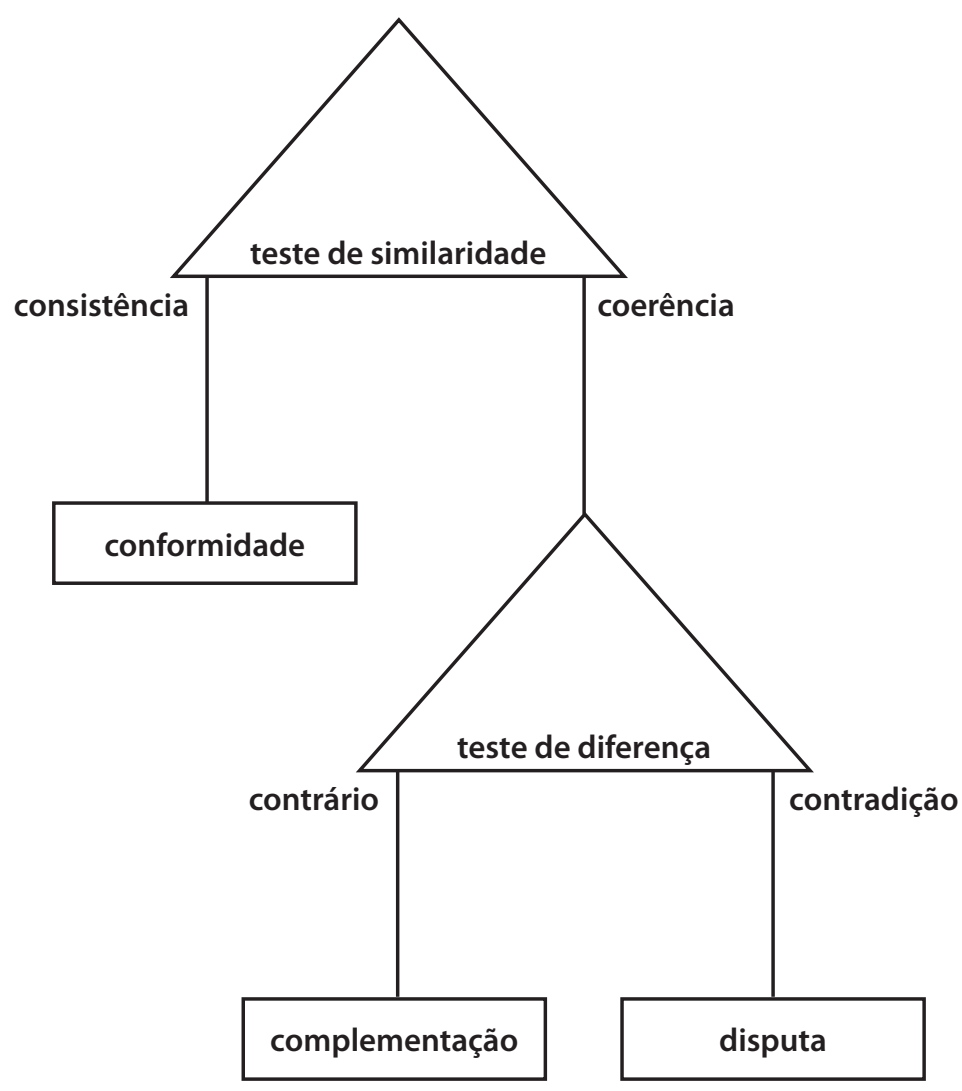

Figura 1 - Modelos multimediais (COOK, 1998: 99)

Se comparamos com o modelo brechtiano, Cook transforma em "teste" o que em

16 Brecht, ao apresentar a tabela com as diferenças entre a forma dramática do teatro e a forma épica, diz: "Este esquema não apresenta oposição absoluta mas simplesmente variações de matiz. Assim, dentro de uma representação destinada a informar o público, podemos fazer apelo tanto à sugestão afetiva quanto à persuasão puramente racional" (BRECHT, 1967: 59)

17 Este primeiro teste tem por base a teoria da metáfora (de George Lakoff and Mark Johnson, 1980) e o segundo tem por base a aplicação musical da semiologia de Greimas (Raymond Monelle, 1992 e Eero Tarasti, 1994). 
Brecht é "pólo", ou seja, onde estão os triângulos similaridade e disputa estariam os dois tipos de estéticas teatrais opostas por Brecht, o teatro dramático e o teatro épico.

O teste de similaridade confere se a transferência de atributos de um elemento para o outro se dá de maneira a criar conformidade entre os dois. Basicamente,

Onde um momento multimedial é conformante, ou onde as relações entre as medialidades constitutivas de um momento multimedial são conformantes, deve ser possível inverter tais expressões sem mudar o significado (Ibidem: 100).

Por exemplo: se em uma cena romântica usa-se uma canção romântica, pode-se fazer com que o texto musical seja falado pelos performers ou que a música cante aquilo que os performers poderiam estar dizendo dentro da cena. A inversão não destrói a conformidade entre os elementos. Dizemos então que a relação entre o texto da música e a encenação é consistente. Do ponto de vista lógico, tende-se à fusão, a uma verossimilhança máxima.

Porém, na prática, geralmente há diferenças mesmo que haja um esforço em escondê-las. O extremo da conformidade "pura" é tão impossível quanto uma mímese no sentido de uma "cópia pura". Vamos tomá-lo mais como uma referência para compreender como os IMM são construídos e organizados do que para efetivamente determinar se os conteúdos projetados e transferidos estão efetivamente em conformidade. Como diz Cook: “(...) conformidade é uma categoria muito menos encontrada para momentos multimediais que a literatura existente poderia levar alguém a supor (...)” (Ibidem: 102).

Porém, a encontramos como um esforço de hierarquização, na valorização de um elemento em detrimento do outro. Se as variações ou diferenças são ínfimas e há um controle para que elas não ocorram, tende-se à consistência mas, se elas aparecem e abrem caminho para outras leituras, a relação entre os elementos se torna coerente, ao invés de consistente e, como decorrência, ficam passíveis ao teste de diferença.

Dependendo do contexto de produção da multimedialidade, pode-se ter consistência em direção à similaridade quando se trata, por exemplo, dos clássicos filmes de Hollywood, nos quais a trilha é feita depois do filme pronto, mesmo que se trate este trabalho como uma complementação. Em sua crítica à literatura existente sobre o assunto, ele aponta dois problemas associados:

O empobrecimento terminológico exemplificado pela categorização tradicional do criticismo de cinema de todas as relações entre música e imagem como paralelas ou contrapontuais, e uma inconsciente (e certamente acrítica) aceitação de que tais relações estão para serem compreendidas em termos de hegemonia ou hierarquia ao invés de interação. (Ibidem: 107).

Já em canções de música pop, apesar de haver uma função complementar entre letra e música, ela ocorre de uma forma não tão hierárquica. (Ibidem: 105).

No teste de diferença indaga-se se os elementos divergem realmente, e em que grau. Se não é uma diferença grande, no sentido da contradição, trata-se de uma diferença num sentido que ainda preserva características comuns, em direção a um contrário. Admite-se 
a hierarquia mas ela não impede a coexistência, a complementação, que pode ser hierárquica (no sentido de haver um tipo de primazia na diferenciação, competitiva ou não), mantendo-se, de alguma maneira, a complementaridade da oposição. Já a contradição “(...) implica um elemento de colisão ou confronto entre dois termos opostos." (Idem).

Cook discute se certos julgamentos sobre conformidades são realmente procedentes, como o de Eisenstein, que se autocritica num sentido de haver conformidade em suas doze pranchas desenhadas para Alexander Nevsky. Ele contesta a autocrítica de Eisenstein, ponderando que a relação entre a visualidade das pranchas não é de conformidade com a música, mas de complementação. ${ }^{18}$

As imagens e a música elaboram o movimento interno em caminhos completamente diferentes, e o resultado é a criação de um relacionamento de diferença semântica entre eles (ao contrário da identidade sinestésica que Einsenstein criticou em si mesmo). E esta elaboração diferencial estabelece uma assimetria entre as duas medialidades; (...) é natural falar da música projetando o conteúdo das imagens, mas não das imagens projetando o conteúdo da música. (Ibidem: 100).

Enfim, a proposta de Cook vê um grau máximo de possibilidades quando a intermedialidade trabalha no sentido de uma disputa, que implica em "uma desconstrução radical dos componentes intermediais, como também em uma geração de novos significados a partir disso" (Ibidem: 106). Caso haja complementação, que ela não se fixe nos elementos e em suas propriedades, mas que resulte "do caminho pelo qual eles são manipulados dentro de um contexto específico”. (Ibidem: 105).

O que nos chama a atenção na musicologia da performance de Cook é a valorização da autonomia dos elementos, que se verifica no contexto de produção e de significação da relação entre os elementos em suas diferenças. Também chama a atenção a proposta de utilização de metáforas (textuais e musicais) dentro deste contexto de relações.

Vamos agora acrescentar estas contribuições ao nosso percurso, como mais uma importante contribuição metodológica, e retomar a análise iniciada por Morley de Barbarasong. Porém, agora propomos uma abordagem da canção que adentra um pouco mais a concretude dos seus momentos multimediais, ou seja, das suas molduras.

\section{4 - Barbarasong em molduras}

Tomando por base o que tem sido comentado até agora neste capítulo, propomos ver a canção Barbarasong dentro de seu contexto. Como parte da cena 3 da Ópera dos três vinténs (1928), Barbarasong é um número musical que se materializa por meio da

18 Cook discorda da crítica que Eisler faz a Eisenstein sobre os quadros das cenas de Alexander Neviski. "Eisler argumenta que a falácia reside no uso da notação musical; o que a análise prova na realidade, ele diz, é que 'há uma similaridade entre a notação musical e a sequência de imagens...A similaridade entre a música e a imagem é indireta, sugerida pela fixação gráfica da música; ela não pode ser percebida diretamente e por esta razão não pode preencher uma função dramática"'. (EISLER apud COOK, Idem: 58. Citado de EISLER, 2007, 105). 
apresentação do texto e da composição musical por uma atriz-cantora. A apresentação deste número interrompe o andamento da cena três, conforme o gráfico abaixo. Nele, reproduzimos o texto de abertura da cena que era projetado nas telas e apresentamos os elementos que a compõe (lista de personagens e canções). O tempo da cena transcorre da esquerda para a direita, as linhas vermelhas demarcam a presença e ausência dos personagens na cena e a área verde demarca o tempo da canção. A medida usada para definir o gráfico foram as páginas do texto em português, portanto não tem por objetivo ser absoluta, mas que possa representar a relação entre os elementos dentro de um fluxo.

\section{Cena 3 Para Peachum, que conhece as agruras do mundo,}

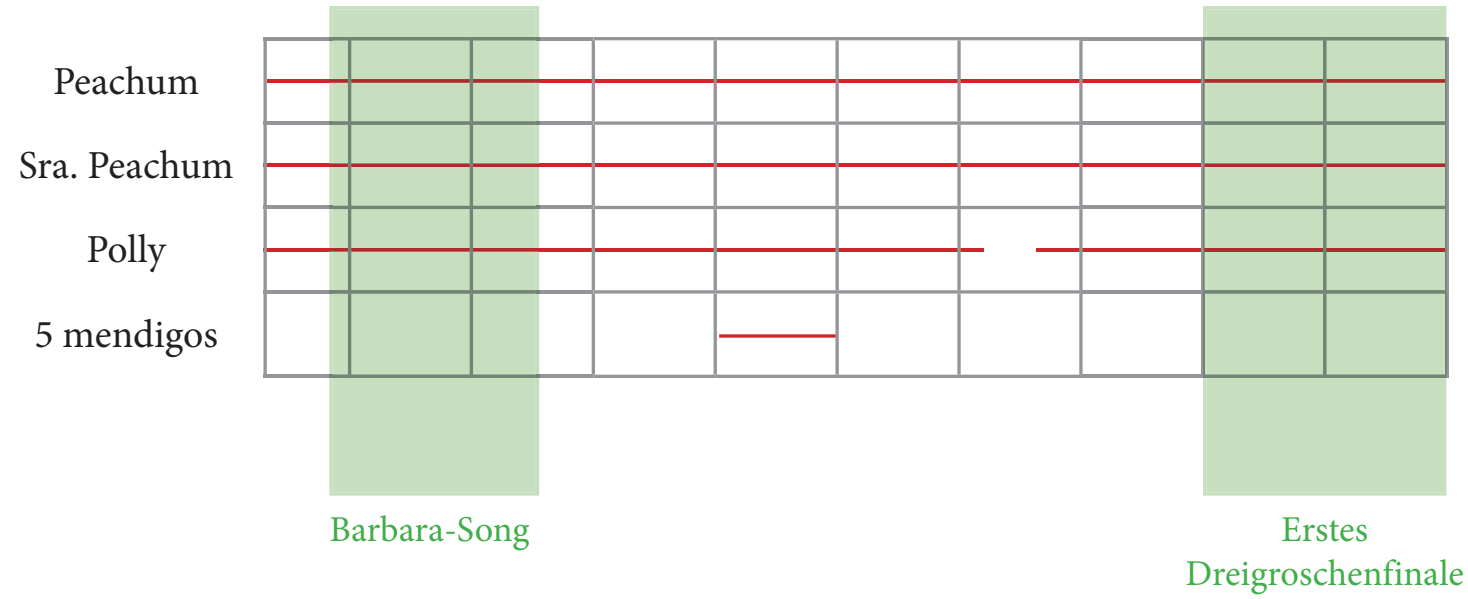

Figura 2 - A ópera dos três vinténs, cena 3

A cena 3 é a cena final do primeiro ato, uma cena de conclusão, e começa no momento em que Polly chega em casa. Após seus pais terem descoberto que ela não dormiu em casa e suspeitarem de sua relação com Mac (cena 1); após ela ter se casado com Mac, inimigo de seu pai (cena 2), Polly chega em casa e é recebida pelos dois que a olham surpresos e indignados. A Sra. Peachum a pergunta imediatamente:

Casada? Primeiro, nós a cobrimos toda de vestidos e chapéus e luvas e sombrinhas, e depois que ela já nos saiu tão cara quanto um transatlântico, ela mesma se joga na sarjeta como um pepino podre. Você casou mesmo? (BRECHT, 1992: 42).

A cena é interrompida em seguida e não há mais tempo para uma contracenação direta. Podemos ver no texto o que ocorre, seguindo a clássica rubrica de Brecht: "Iluminação para canção: luz dourada. O órgão é iluminado. Do alto da cena descem três refletores presos a uma barra. Nos letreiros lê-se: 'Com uma pequena canção, Polly insinua aos pais seu casamento com o ladrão Macheath"' (Ibidem: 42-43). A partir deste momento começa a canção.

Notem que a música não começa de imediato, pois há primeiro uma descida dos re- 
fletores e a projeção de um novo texto. Esta interrupção do naturalismo com uma movimentação dos "aparatos" demarca nitidamente uma ruptura com a própria representação, e nos traz o que Benjamin chama de "ligar e desligar" a cena ${ }^{19}$. A canção é anunciada por um letreiro que vai direto ao ponto, sem que se prepare uma surpresa a ser apresentada gradualmente no envolvimento com os eventos apresentados.

Com o aparecimento dos aparatos, Polly não canta somente para os pais, mas também para a platéia. A cena então muda de função. E o texto também, pois a letra da canção conta uma história, sem que o público saiba se Polly fala propriamente dela ou narra em outra pessoa. Polly "insinua". Rompe-se a moldura da contracenação naturalista e instala-se a moldura da canção.

Torna-se importante compreender, nesse sentido, a relação que estamos estabelecendo entre o estranhamento brechtiano e uma "ruptura de moldura" da forma como estamos afirmando. Na medida em que a cena naturalista é mantida, as molduras teatrais necessitam ser mantidas para que a situação também se mantenha construída. A ruptura com o naturalismo significa uma interrupção deste fluxo de reproduções. Antes tínhamos a moldura teatral organizada e fluindo em sua mímese, duplicando-se conforme a encenação se propunha fazer diante do espectador. Com chegada de Polly, os olhares de reprovação de seus pais, a fala crítica e debochada de sua mãe, vemos que todos estes elementos mantinham, por assim dizer, a reprodução de molduras teatrais apresentadas continuamente, definindo uma forma espaço-temporal da apresentação. A transformação desta moldura teatral ${ }^{20}$, como dizia Goffman em sua leitura do que Brecht propõe, significa "chamar periodicamente a atenção para o caráter fictício do todo, de modo a não permitir à platéia manter por muito tempo um conjunto de laminações" (GOFFMAN, 2012: 492). O distanciamento, para Goffman, pode ser detalhado pelos múltiplos "canais" ou "laminações" que articulam a cena e que, num dado momento, são reconfigurados. Como comenta Yves Winkin, "o 'quadro-análise' de que Goffman fornece todos os elementos é muito diretamente operacional: permite decompor qualquer situação nos seus diferentes registros existenciais" (WINKIN, 1999: 94). Assim, o argumento de Goffman caminha num sentido fenomenológico e multimedial. O "pôr entre parênteses" é mantido, reproduzido e, mediante uma determinada tensão estabelecida em seus limites, pode se romper para se reconfigurar em outro nível de complexidade. Goffman trata o processo de significação teatral como articulação transformadora de situações de apresentação especificamente configuradas (molduras), tanto em sua materialidade como em

19 Em Que é o teatro épico - Um estudo sobre Brecht, de 1931, Benjamin salientava o uso de técnicas cinematográficas de montagem aplicadas ao espetáculo teatral, expandindo e detalhando a separação dos elementos enquanto formas de atuação e encenação com cortes rápidos. Eram os dispositivos audiovisuais de cena, esse "mostrar", desde o ator até todos os outros elementos, em sua capacidade de "ligar e desligar" a apresentação, aproximar e afastar-se, estar presente e desconstruir a presença. Porém, aplicadas ao teatro, as técnicas cinematográficas se transformavam (BENJAMIN, 1987: 78-90).

20 Para uma introdução a Goffman e o conceito de moldura, ver https://www.academia.edu/2157533/ Performance_e_análise_de_molduras_-_A_contribuição_de_Erving_Goffman_para_o_teatro 
suas formas de apresentação-interpretação, ou seja, nas suas relações palco-plateia.

Podemos explorar outras possíveis molduras. A canção ocupa o lugar de uma reação que Polly teria diante do confronto com seus pais. Se não houvesse a canção, como seria? Na contracenação, a resposta de Polly aos pais poderia ser "vou me casar, por que não?" ou, transformando a canção em um texto simples, Polly argumentaria sobre o apego ao luxo, à pompa e ao cavalheirismo vazio. E por fim diria que se casou com um bandido porque ele não correspondia ao papel romântico que tanto a aprisiona. Mas ainda estaríamos reproduzindo e mantendo o fluxo de molduras naturalistas criadas. Uma outra alternativa para Brecht quebrar o fluxo de molduras naturalistas seria se utilizar apenas da projeção visual, do movimento dos holofotes, ou concentrar-se na performance física e gestual dos atores para demarcar o gestus da cena. Ele não precisaria necessariamente da canção. Brecht utilizou o distancimento em outros espetáculos, e deve-se dizer que ele procurou desenvolver técnicas de atuação específicas em direção a estas rupturas. Mas, em Dreigroschenoper, Brecht e Weill descobriam a canção como um recurso privilegiado para esta quebra de molduras, ao utilizar-se do antigo modelo metastasiano de ópera onde a canção interrompe a ação e passa a envolver a platéia de outro modo. Durante as canções deste espetáculo, os atores-cantores se dirigem à platéia, mas isto não é uma regra geral. Há canções onde a mímese da contracenação (utilizando a quarta parede) é interrompida e a performance da canção "olha" para a platéia. Há outras cantadas no proscênio. Há aquelas que interrompem a contracenação, mas são cantadas para a própria cena. Há canções que recebem e outras que não recebem a rubrica textual "Iluminação para a canção: luz dourada..... Enfim: há vários tipos de canções e de relações específicas que elas criam com o espetáculo e com a platéia. Barbarasong é uma canção que recebe a rubrica épica de Brecht já comentada: luz dourada, luz no órgão, três refletores se abaixando, letreiros sendo projetados. Além disso, é uma canção que se dirige também ao público, e que interrompe um contexto de contracenação que vinha em andamento. Em cançõse como a Balada da boa vida (Ballade vom angenehmen Leben), na cena 6, no final do segundo ato, Macheath está na prisão e canta diretamente para a platéia. Há os refletores que descem do alto, o título da canção projetado, a luz no órgão, mas não há uma contracenação "assistindo-o" 21 .

Polly canta e configura um gestus inicial que é o aparecimento da canção. Mas, dentro desta nova moldura, Polly também vai trabalhar com as transformações que esta moldura oferece. Isto significa utilizar os quatro episódios (elencados por Morley) separados por suspensões, demarcando diferentes "situações" musicais onde os rastros da canção (melodia, andamento, ritmo, etc.) se configuram de maneiras diferentes, relacionando-se com a letra e com a atuação. Vamos ver então algumas possibilidades destas laminações que a moldura da canção poderia oferecer. Começando com os andamentos e dinâmicas, a partitura mostra:

21 Há uma foto histórica desta cena em: http://www.tagblatt.de/Home/nachrichten_artikel,-WieHerr-Koch-waehrend-der-„Dreigroschenoper“-auf-den-Ausloeser-drueckte-_arid,52115_ print,1.html Foram exibidas, numa exposição, 25 fotos de cenas feitas por Carl Koch, diretor de cinema alemão e amigo de Brecht, conforme atesta o jornal Tagblatt. Acesso em 11.02.2015. 
1 Moderato assai

2 Piano $(p)$ - poco rit. [mais lento] Transição - Accel. [acelerado]

3 Piu animato [mais animado] Transição - Piano $(p)$ e suspensão com duas fermatas

4 Breit (largo)

Cada um destes momentos se relaciona com o texto e com a cena de uma maneira diferente. A música é composta por três estrofes, e em cada um delas estes quatro estágios se repetem, nesta ordem. Vamos agora mostrar apenas a primeira estrofe e como os efeitos musicais de cada estágio criam relações com o texto ${ }^{22}$. Apresentamos abaixo os quatro episódios e suas divisões internas em "A" e "B".

Andamentos (em semínimas)

1 Moderato assai

A quando eu era moça, quando eu era pura um dia eu fui pura também

B por deus eu sabia que um dia viria um rapaz, o meu príncipe, o meu bem

\section{Piano}

A se fosse lindo, se fosse rico, com anéis brilhando em sua mão

B e me tratasse assim como uma lady eu lhe diria: não

3 Piu animato

A eu iria me esconder atrás de meus perfumes e dos meus sais

B lá na terra a lua tudo vê cá na terra tenho que me proteger eu não posso relaxar

4 Breit

A eu não devo ser assim tão lúbrica e entregar-me assim a um varão

B é preciso ser sempre fria e sempre dizer sempre: não

22 A tradução aqui utilizada foi retirada do espetáculo "A dama indigna - um conceito de cabaré" e, para uma melhor compreensão, apresentamos o endereço de uma filmagem do espetáculo no Youtube, na qual Cida Moreira interpreta esta canção: https://www.youtube.com/watch?v=L_ HFPqBtG1k. Para ouvir a versão em alemão, acessar https://www.youtube.com/watch?v=r6xIIHFhZgg\&list=PLF016038928C41E0C\&index $=8$. 
Primeiro Polly introduz-se em uma história romântica e apresenta a sua expectativa idealizada. Podemos observar que, neste estágio 1 da canção, há um interessante jogo de intervalos no desenho melódico que articula o texto de uma forma circular, ao utilizar apenas intervalos de terças menores e segundas menores, tomando a nota dó como centro. Este recurso funciona como uma metáfora do "contar da história" por parte de Polly (ver Figura 3). Pode-se também trabalhar com esta circularidade com um texto que pretende "apresentar motivos" diante de uma acusação, ou de "buscar argumentos", por exemplo.

1

A quando eu era moça, quando eu era pura ${ }^{23}$ um dia eu fui pura também

B por deus eu sabia que um dia viria um rapaz, o meu príncipe, o meu bem $(=63)$

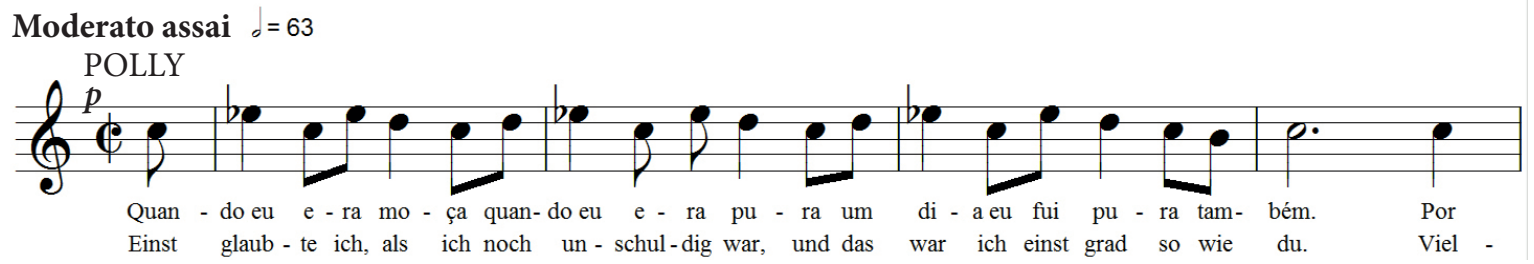

Figura 3 - Barbarasong - Compassos 1 a 3 (Weill, 2000: 32)

No estágio 2, com uma dinâmica mais suave (o andamento que cai para a metade da velocidade), Polly acentua ainda mais o romantismo. A melodia comporta pausas, que parecem suspiros, e vai caindo o andamento na medida em que traz elementos descrevendo o "príncipe". Esta diminuição de ritmo (poco rit.) chega quase a uma suspensão completa, e então ela diz "não", jogando por terra o anunciado romantismo. O sentido do texto é conduzido de 1 para 2 no sentido de haver uma possibilidade de encontrar este príncipe. Estas duas primeiras partes mostram os estágios criados por Weill com base no texto de Brecht. A ingenuidade, ironia ou duplicidade apresentada pode ser trabalhada por meio da música de Weill e da fixação rítmica do texto por meio do gestus ${ }^{24}$. Em seguida, há uma mudança mais radical de 2 para 3, pois apresenta-se uma inversão. O estágio 3 se inicia com uma reviravolta rítmica (accel.), representada na partitura por uma série de colcheias subindo na clave de sol e descendo na clave de fá.

23 Aqui sublinhamos em azul as sílabas que são cantadas em dó.

24 A fixação rítmica do texto era um dos objetivos de Weill com o gestus. "Quais são os significados gestuais da música? Primeiro, o gestus é expresso em uma fixação rítmica do texto. A música tem a capacidade de grafar as ênfases da linguagem, a distribuição de sílabas curtas ou longas e, sobretudo, pausas". (WEILL, 1979: 493, tradução nossa) 


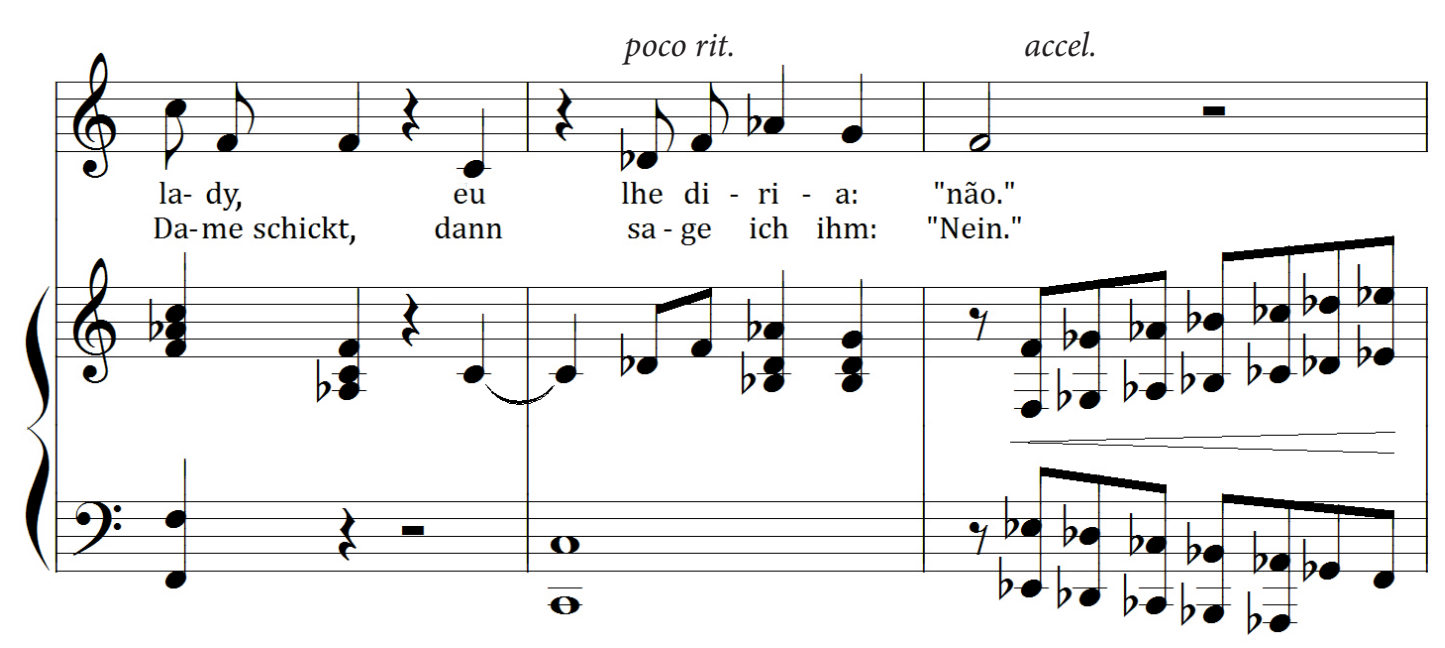

Figura 4 - Barbarasong - Compassos 14 a 16 (WEILL, 2000: 33)

O piano faz uma preparação para uma atitude afirmativa por parte da cantora, com mais energia, após dizer "não". O texto agora tem um tom de uma resistência exposta, transformada em fuga para a fantasia. $\mathrm{O}$ andamento e o texto sugerem, juntos, um momento de maior contraste. Por fim, a quarta parte reafirma o "não" de um ponto de vista mais moral e racional. Nesta parte, Weill compõe um gestus rítmico mais próximo a uma marcha lenta, arrastada, usando um largo, que pode ser aproveitado pelo intérprete como momento de introspecção ou tristeza, por exemplo.

\section{5 - Considerações finais}

Falamos até agora da quebra de molduras de cena que as canções representam e de como a configuração que elas inauguram com seu gestus traz múltiplos processos de significação concomitantes: a) os rastros musicais (como os identificados nas partituras, como andamento e linha melódica, por exemplo) trazem sugestões aos performers-intérpretes; b) os aparatos (como luz e letreiros) fazem mudar o foco da cena e anunciam um texto-resumo do que irá acontecer; c) o canto traz também uma mudança na relação palco-platéia conforme o que propõe: se valoriza o contexto de contracenação, podem cantar para a cena; se rompe mais radicalmente com este contexto, passa a cantar diretamente para a plateia (podendo até cantar do proscênio, com as cortinas baixadas), entre outros.

Observamos também que a performance destas canções é subdividida em estágios, que Morley identificou em Barbarasong, e mostramos em linhas gerais que o texto e a canção trazem elementos distintos a cada um destes estágios, configurando uma articulação entre eles que abre caminhos para a performance do material de cena, não fazendo apenas a concordância destes elementos, mas podendo explorar estas articulações de diversas maneiras, que Cook detalhou em seu método, em momentos multimediais de conformidade, complementação e disputa.

Observamos, conceitualmente, que há um alinhamento entre os conceitos de "estágio" (Morley), momento multimedial (Cook) e moldura (Goffman). Em linhas gerais eles estão falando de como os elementos (texto, música, performance, encenação, recepção, etc.) podem se articular e produzir significação musical através de diferentes formas e 
configurações. O gestus, em especial, é um destes momentos e tem a peculiar característica do "mostrar" a performance e sua sustentação, de alguma maneira transitando entre uma cena constituída e os desdobramentos que as fissuras ou rupturas que esta configuração pode suscitar. $\mathrm{O}$ gestus suspende um andamento anterior, ele secciona.

Fizemos apenas uma abordagem da canção Barbarasong para demonstrar como se poderia desenvolver um trabalho com mais detalhes em torno das canções de Brecht e parceiros musicais. Aqui sugerimos possibilidades, que devem se adequar ao tipo de processo criativo (ou analítico-criativo) a ser empreendido com base em um material como este. A análise pode prosseguir em diversas frentes e faltou aqui falar em especial do texto como elemento que se desdobra em momentos intermediais distintos. Em geral, o texto poético de Brecht para as canções traz uma outra situação, diferente da encenada, o que possibilita um primeiro distanciamento. Depois, o texto oferece ao menos duas tendências: uma que estabelece um vínculo com a situação de fala do personagem, com o tipo de naturalismo que a canção traz (como em "quando eu era pura, quando eu era pura"), e outra que traz metáforas poéticas mais amplas (como em "lá na terra a lua tudo vê"). Outro aspecto é o ritmo e acentuação, que configuram valores musicais a partir do texto falado, numa sintaxe rítmica que também configura um gestus a ser performado, seja na fala, seja no canto. Ou seja, o texto de Brecht também possui seus rastros sonoro-musicais.

Além da pequena análise do desenho melódico apresentada, sugerimos que outros rastros musicais identificáveis possam também ser explorados, como:

- Expressividade e dinâmica/intensidade (da melodia e do acompanhamento).

- Curva rítmica: andamento; fórmulas de compasso e suas variações; aceleração ou diminuição no número de notas cantadas por compasso.

- Articulações sugeridas pela partitura.

- Organização harmônica por meio de graus, progressões e relação entre as linhas (vocais ou instrumentais). Maneiras de lidar com a tonalidade.

- Partes faladas e partes cantadas previstas na partitura.

- Arranjo e orquestração.

\section{Referências}

BENJAMIN, Walter. Magia e técnica, arte e política - obras escolhidas. Vol. 1. São Paulo: Editora Brasiliense, 1987.

BRECHT, Bertolt. Teatro Dialético. Rio de Janeiro: Editora Civilização Brasileira, 1967. A ópera dos três vinténs. Escrita em 1928. Estréia: Berlim, 1928. Tradução: Wolfgang Bader e Marcos Roma Santa. Versificação das canções: Wira Selanski. In: Brecht, Bertolt. Teatro Completo em 12 volumes. Paz e Terra, v. 3: 9-108, 1992.

COOK, Nicholas. Analysing musical multimedia. Oxford: Oxford University Press, 1998. 2007.

Music, performance, meaning. Selected Essays. Ashgate Publishing Limited, 
EISLER, Hanns; ADORNO, T. W. Composing for the films (1947). London, New York: Continuum Impacts, 2007.

FISCHER-LICHTE, Erika. Theatre, sacrifice, ritual. Exploring forms of political theatre. Oxon: Routledge, 2005.

FOWLER, Kenneth Ray. Received truths: problems of the music-text relationship and Bertolt Brecht. Thesis, McGill University, Montreal, 1987.

GILBERT, Michael John Tyler. Bertolt Brecht's striving for reason, even in music. New York: Peter Lang Publishing, 1988.

GOFFMAN, Erving. Os quadros da experiência social: uma perspectiva de análise (Frame Analysis, 1974). Tradução de Gentil A. Titton. Petrópolis: Editora Vozes, 2012.

LEHMANN, Hans-Thies. Teatro pós-dramático (1999). São Paulo: Cosac Naify, 2007.

MORLEY, Michael. "Suiting the action to the word": some observations on gestus and gestische Musik. In: Kowalke, Kim H. (Ed.). Essays on a new orpheus - Kurt Weill. New Haven and London: Yale University Press, 1986.

MÜLLER, Heiner. To use Brecht without criticizing him is to betray him. From: Brecht Jahrbuch 1980, Reinhold Grimm and Jost Hermand eds. (Frankfurt, 1981), pp. 14-21 (Title: Keuner-Fatzer) presented at: 5th Congress of the International Brecht Society, University of Maryland, March 1979.

RAMBO-HOOD, Markee $\mathrm{H}$. What a difficult task it is for music to fulfil the demands of an epic theatre: a discussion of the role of epic music in Bertolt Brecht's plays. Glasgow, 2009.

TRAGTENBERG, Livio. Música de cena. São Paulo: Perspectiva, 1999.

WEILL, Kurt. Concerning the gestic character of music (1929). In: Kowalke, Kim H. Kurt Weill in Europe. UMI Research Press, Apêndice II: 491-496, 1979.

; Brecht, Bertolt. Die Dreigroschenoper. Ein Stück mit Musik in einem Vorspiel und acht Bildern. Klavierauszug. UE 31544. Universal Edition, 2000.

WINKIN, Ives. Os momentos e os seus homens - Erving Goffman. Lisboa: Antropos, 1999. 